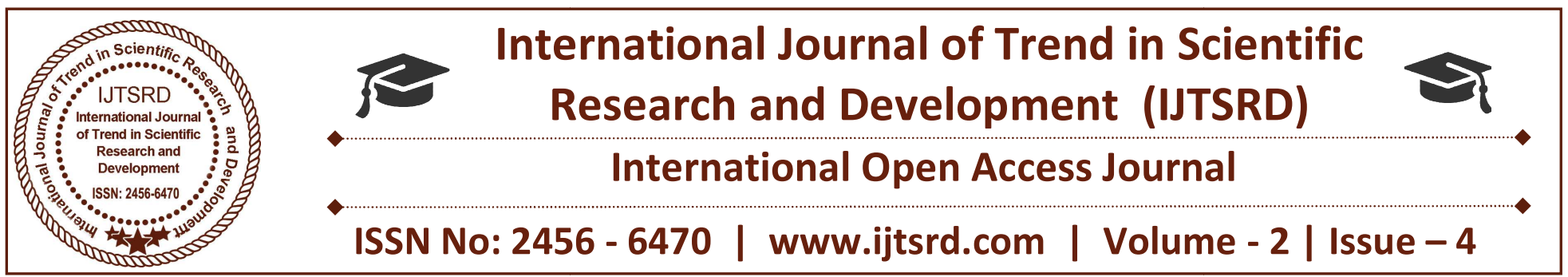

\title{
A Study of Contribution of Balgram in Socialization and Rehabilitations of Orphan Children in Maharashtra State
}

\author{
Ashok Ghadge \\ Ph.D Student, Bharati Vidhyapeet University, Pune, Maharashtra, India
}

\section{ABSTRACT}

In this paper, contribution of child care institution/ Balgram in socialisation and rehabilitation of orphan children in Maharashtra State is explored. In Maharashtra state 14 NGOs are running Balgram/Balsadan/Balgruh, which 8 is based on international concept of Balgram of SOS Children villages. In Balgram child care plan, Children given long term supports for their holistic development, accordingly activities are planned and implemented so children should grow with respect, self confidence and self image. Most important is children get family environment, especially emotional supports from Balgram Staff. House mother/ care taker is heart of Balgram concept. The children grow as a brother and sisters in family home. Rationale of the study, Orphan children are more vulnerable demands more care and support. The children have lots of potentials, which need to understand and channelize them in proper way and direction. The child development is depends upon the quality of socialization. Balgram has adopted family based concept and actual taking lots of efforts to socialize the children. There is close association between socialization and rehabilitation. The researcher wanted to explore this association in scientific way Objective of the study are to study socilisation and rehabilitation process of Balgram, contribution of Balgram, scope of social work intervention and to explore the problems and prospects of Balgram Children. Based on these objective hypothesis are Socialization process of Balgram and rehabilitation of children may be closely associated to each other, Balgram provides family set up to the children who are in need of care and protection and Balgram play an important role in rehabilitation of the children who are in need of care and protection through socialization Explanatory research design, all the children of Balgram age 13 to 18 are included, Sample size: 277 current children +65 pass out children +46 Balgram staff $=388$ and Sampling method: Mixed sampling (Randomly and snow ball method). In data analysis cross tables are prepared according to the gender; Chi-square test is applied to understand the association between the two variables. Socio-economic status of the rehabilitation children is assessed according to the Kupuswami method (2017 indicators) Hypothesis testing explained along with conclusion and suggestions

\section{INTRODUCTION}

Children are the first call on agenda of human resource development $\rightarrow$ not only because of their vulnerability but also the foundation for lifelong learning's and human development which is laid in these crucial early years. It is now globally acknowledged that investment in development of human resources is a pre-requisite for economic development of nation. Early childhood (the first six years) constitutes the most crucial period in life, when the foundations are laid for cognitive, social, emotional, physical development and cumulative lifelong learning's. During this process the holistic approach is needed for development of any child. There should be balanced linkages between education, health and nutrition.

India is like a home for the largest child population in the world. Hence the Tenth Five Year Plan (2002-07) underlines the fact that "the development of children is the first priority on the country's development agenda, not because they are the most vulnerable, but because they are our supreme assets and also 
the future human resources of the country". Further the Eleventh Five Year approach paper indicates that the child is a center point of development.

The government is taking lots of efforts for child development through policies, programmes and schemes. At judicial level basic rights have given to children. Further the law gives guidelines to the society about how to behave with the children. The basic provisions of the children included the following things.

\section{Review of literature}

Children are an assets and future of our country. They bring the development $\&$ prosperity to the country. But as we all know that the children are the most vulnerable part of the society $\&$ can be easily targeted. In India we have enacted many laws \& Acts related to Children in order to protect them $\&$ to give them a better \& sound development.

Balgram is a children home run by NGO which provided long term family base care for children in needs care and protection. The children are getting various facility for all round development e.g. cognitive, emotional, social, self-development, selfefficiency and competencies. Apart from basic need of the child, Balgram provides good life, warmth and loving family environment, family relations of brothers and sisters and mainly emotional and mental strong supports. The trained employees of Balgram have knowledge on early childhood service, child care, child rights, how to promote creativity, what's holistic development, how to monitor child growth, preventive of diseases, protection of child from accident etc.

Balgram is a unique concept which need to be explored along with their contribution in socialization and rehabilitation of children in need care and protections. Socialization and rehabilitation are both side of one coin. There inter dependency needs to be checked.

An Orphan: The most accepted definition of an orphan is a child who has lost both parents through death. (http://www.dictionary.com) In this study the definition of an orphan includes all children under the age of eighteen who are maternal (an orphan who has lost only their mother), paternal (an orphan who has lost only their father) or double orphans.

\section{Socialization}

Throughout, the development of child depends upon the socialization process. Socialization process is important because it plays a significant role in deciding aspiration of life. Basically, socialization is a process of acquiring norms, customs and ideology. It may help to achieve the required skills and habits necessary for pertaining within their own society. Generally it is education where an individual adopt the social rules and regulation which is necessary to interact with the others or to live in society. The socialization process may affects the nature and structure of family, the economic status of the family, the religion of family, the education level of family members, total number of family members, overall surrounding of the society, culture of society, the political, social, economical condition of the society etc.

Socialization is the process by which children and adults learn from others. We begin learning from others during the early days of life; and most people continue their social learning all through life (unless some mental or physical disability slows or stops the learning process). Sometimes the learning is fun, as when we learn a new sport, art or musical technique from a friend we like. At other times, social learning is painful, as when we learn not to drive too fast by receiving a large fine for speeding.

\section{Institutional socialization of children}

There are different types of institutions. Presently Government Organizations (GOs) and Non Government organizations (NGOs) are running these institutions. The provisions of getting basic facilities have been made by these institutions but as far as psychological needs are concern the children may be deprived from emotional and family support. No doubt that the institutions may provide basic facilities as per requirement which is again necessary for overall development of child but there are always issues of fulfillment of psychological needs of every child. It may vary institution to institution. Within all the institution the concept of SOS Children VillagesBalgram has got great success.

SOS Children's Villages is the English name of the entire organisation. SOS Children's Villages is a private child welfare organisation which provides long-term family-based care for orphaned and destitute children. 
The Second World War had left thousands of children orphaned, homeless and traumatized. Many of them found themselves in overcrowded orphanages, separated from their brothers and sisters and grouped according to age and gender. Convinced that a family environment would give these children a better foundation on which to build their lives, Gmeiner, a medical student, challenged traditional methods of orphan care and pioneered a family-based approach. The first SOS Children's Village was established in the small Austrian town of Imst in 1949 by Hermann Gmeiner.

His concept was - and continues to be - based on four principles: each child needs a caring mother or parent, who builds a close relationship with each individual child. The children grow up with girls and boys of different ages as brothers and sisters in their own family house in a supportive village environment. Siblings are not separated and the village provides additional professional care, education and a village community to prepare the children for a self-reliant future.

\section{History of Balgram Maharashtra}

In Maharashtra SOS Children Villages Balgram movement was started by Lt. D. T. Jadhav, Ex, Director of Women and Child Welfare Pune in 1974. The first Balgram was started in Maharashtra at Village Gagode, it is Pen Tehsil District Raigad, birth place of Mr. Vinobaji Bhave a social activist and freedom fighter.

Following Non-Government/Organizations (NGOs) are running Balgram SOS villages following Balgram international concept of SOS Children's Village. All following those are affiliated to Balgram Maharashtra.

There are 14 NGOs are running Balgrams of international concept of Balgram in Maharashtra.

Balgram SOS Yerawada Pune, Shree Dilipsing Raje Ghatge Balgram Panhala District Kolhapur, Pachdeep Sankul Balgram Panwel Dist Riagad, Neela Balsadan Ambernath Dist Thane, Dr. Hermann Gmeiner Social Centre Pune, ISC'S ABBalgram Lonavala Dist Pune, Sampark Balgram Malavali, Pimpalgaon, Dist Pune, Ashray santa Malegaon Dist Nasik, SSM's Anand Balgram Sagroli Dist Nanded, Kastrubha Gandhi Trust Balgram Sasawad Dist Pune, Kasturbha Trust Dharani Nagpur, Balmandir Nagapur, Vishudha Bal. Yawatamal

\section{Rationale of the study}

Orphan children are more vulnerable demands more care and support.

$>$ The children have lots of potentials. This need to understand and channelize them in proper way and direction.

$>$ The development depends upon the quality of socialization.

$>$ Balgram has adopted family based concept and actual taking lots of efforts to socialize the children.

$>$ The researched wanted to assess the outcome of efforts taken by Balgram.

$>$ Rehabilitation depends upon the socialization. The researched wanted to evaluate the efforts taken by the Balgram whether helped the children in their rehabilitation.

$>$ Apart from the proper socialization there are other factors which affect the rehabilitation. The researcher wanted to explore these factors.

$>$ There is close association between socialization and rehabilitation. The researcher wanted to explore this association in scientific way.

Recently Women and Child Development Department (State Government) declared that all children home are "BALGRUH", as a result Balgram concept is being neglected even though it is the best and basic alternative care for orphans.

To internalize the socialization process of the Balgram in context of overall rehabilitation of the Balgram children and to assist in smooth functioning of the day to day activities and explore contribution of Balgram for orphans are some of the key areas attracted the attention of the researcher for choosing the topic.

\section{Objectives of the study}

1) To study family based institutional set up of Balgram with reference to the changing situation of society

2) To study the socialization and rehabilitation process of Balgram

3) To study the contribution of Balgram in socialization and rehabilitation of the children

4) To explore the problems and prospects of Balgram children

5) To study the scope of social work methods with reference to socialization and rehabilitation of Balgram children 


\section{Hypothesis}

1) Socialization process of Balgram and rehabilitation of children may be closely associated to each other

2) Balgram play an important role in rehabilitation of the children who are in need of care and protection through socialization

\section{Scope of the study}

Useful to understand their own activities in more scientific way

Activities, efforts taken by the Balgram can be highlighted through this study

$>$ Useful for increasing the financial resources of the organization

$>$ Children will get more inputs from the professional social worker

Helpful to sensitize the government

\section{Socialization is measured according to the following indicators}

Provision of physical family environments, Provision of basic facilities, Age appropriate education, Age appropriate physical development, Provision of coping mechanism system, Provision of facilities for physical and mental development, Adoption of social etiquettes and manners, Creation of Social network, Monitoring and supervision system, Firsthand experience on the daily routine activities Entertainment facilities, Information on social norms, Awareness and firsthand experience in social culture, Experience on participatory approach, Scope for the

development of personal skills, Lifelong connectivity with the institution

Rehabilitation is measured according to indicators Education, Socio-economic status, Marital status. (KUPUSWAMI METOD 2017)

Parents: It includes Balgram-Director, House Mothers, Care Takers and Child Counselor is the parents of institutionalized Children.

Balgram/Institutionalized children: - These are the children from Balgram SOS Children's Village run by Nogs in Maharashtra it residential long care of the child.

\section{Research Design;}

Type of research: Explanatory

Universe: All the Balgrams of Maharashtra

$>$ Sampling method: Mixed sampling (Randomly and snow ball method)

Sample size: 277 current children +65 pass out children +46 Balgram staff $=388$

\section{Data Analysis}

In Indian society the socialization is differ from gender to gender hence the cross tables are prepared according to the gender.

$>$ Rehabilitation process of Balgram is depending upon the gender of the children hence rehabilitation data is presented according to the gender of the respondents.

Chi-square test is applied to understand the association between the two variables. 
Socio-economic status of the rehabilitation children is assessed according to the Kupuswami method (2017 indicators)

\section{Total Number of Students Covered}

Total Balgram in Maharashtra: 14 Existing number of children in Maharashtra: 683

Total children covered: 277 (Source-

Krejcie and Morgan Model)

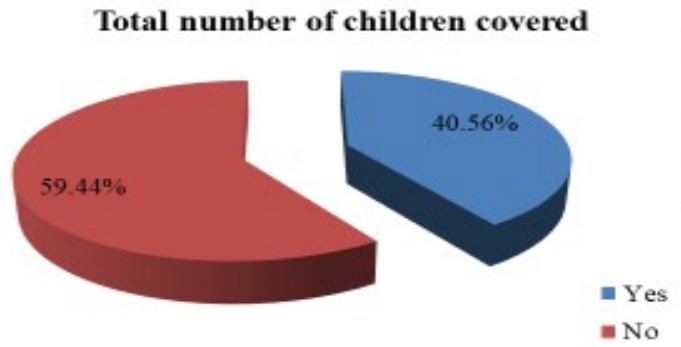

$N=683$

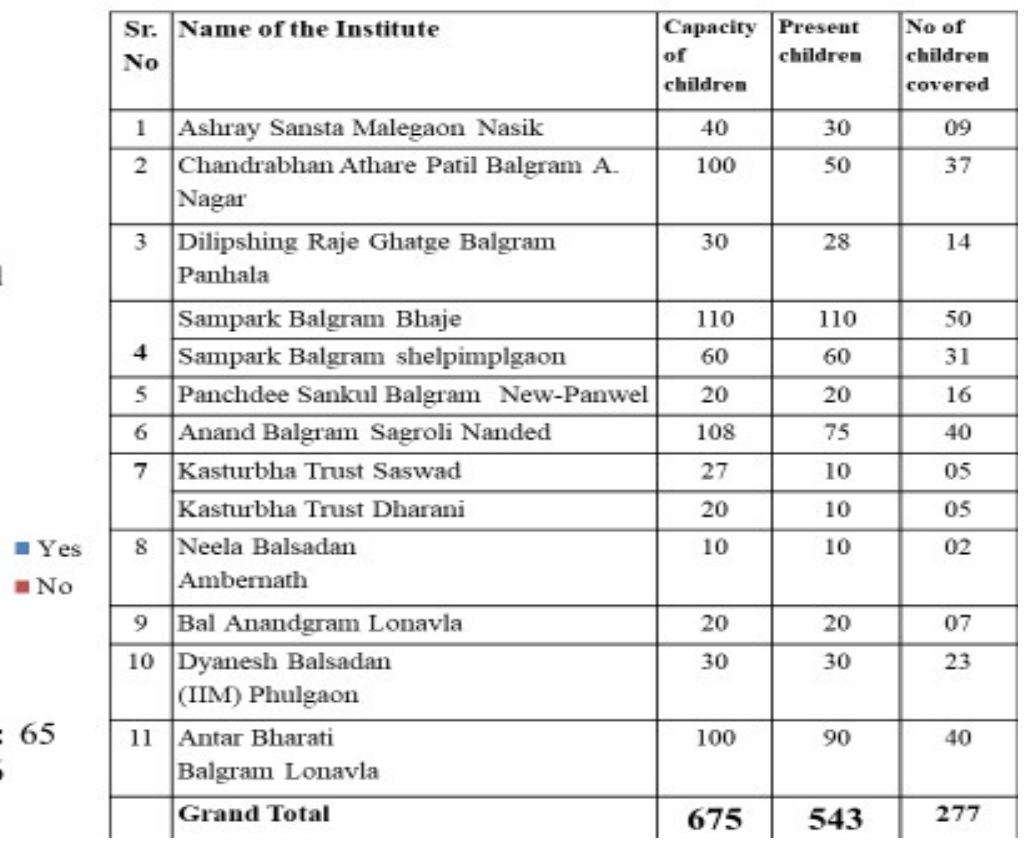

Number of pass out children covered: 65

Number of Balgram staff covered: 46

\section{Profile of Pass Out Children}
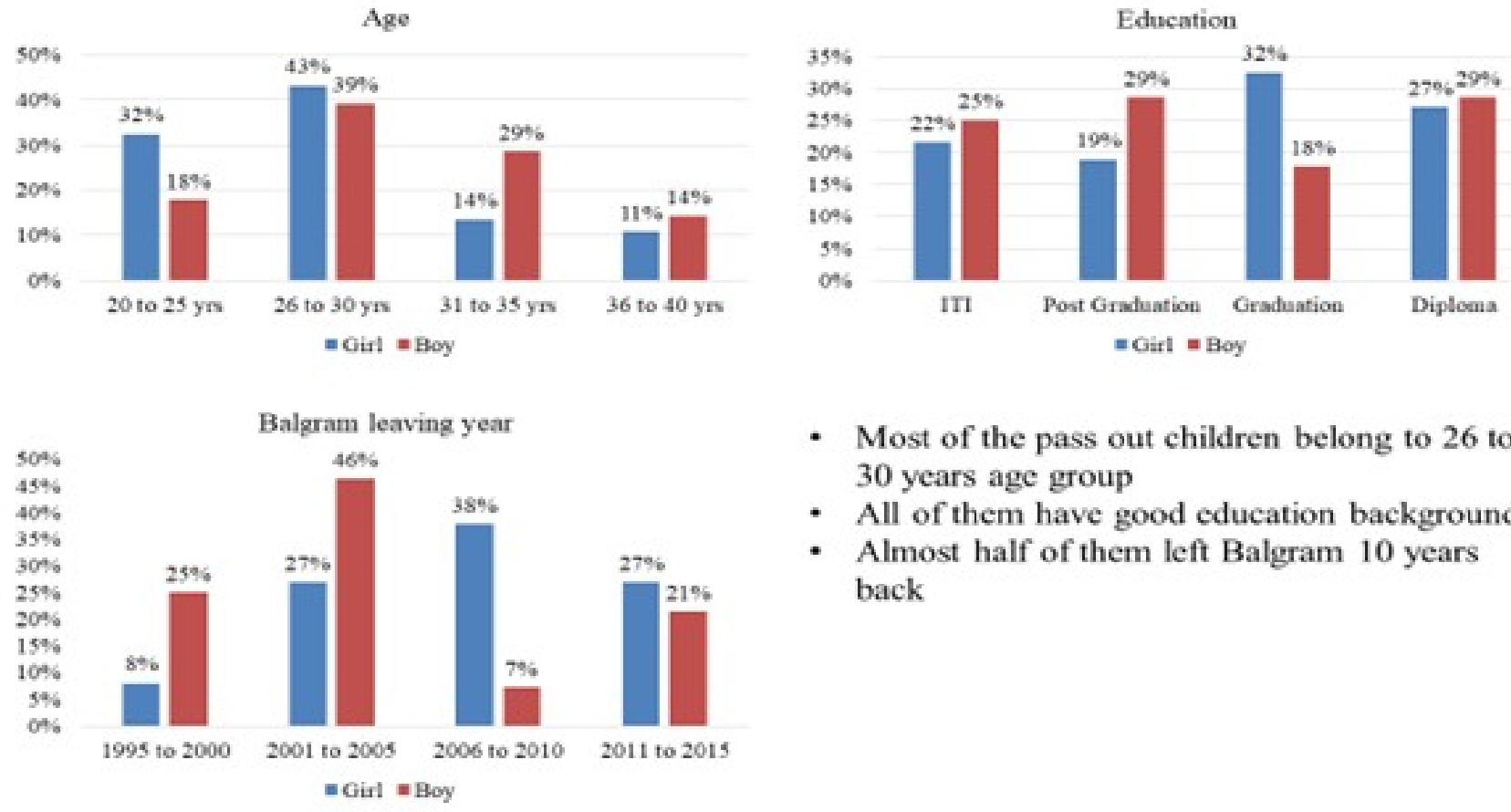

- Most of the pass out children belong to 26 to 30 years age group

- All of them have good education background

- Almost half of them left Balgram 10 years back 


\section{Profile of Current Children}
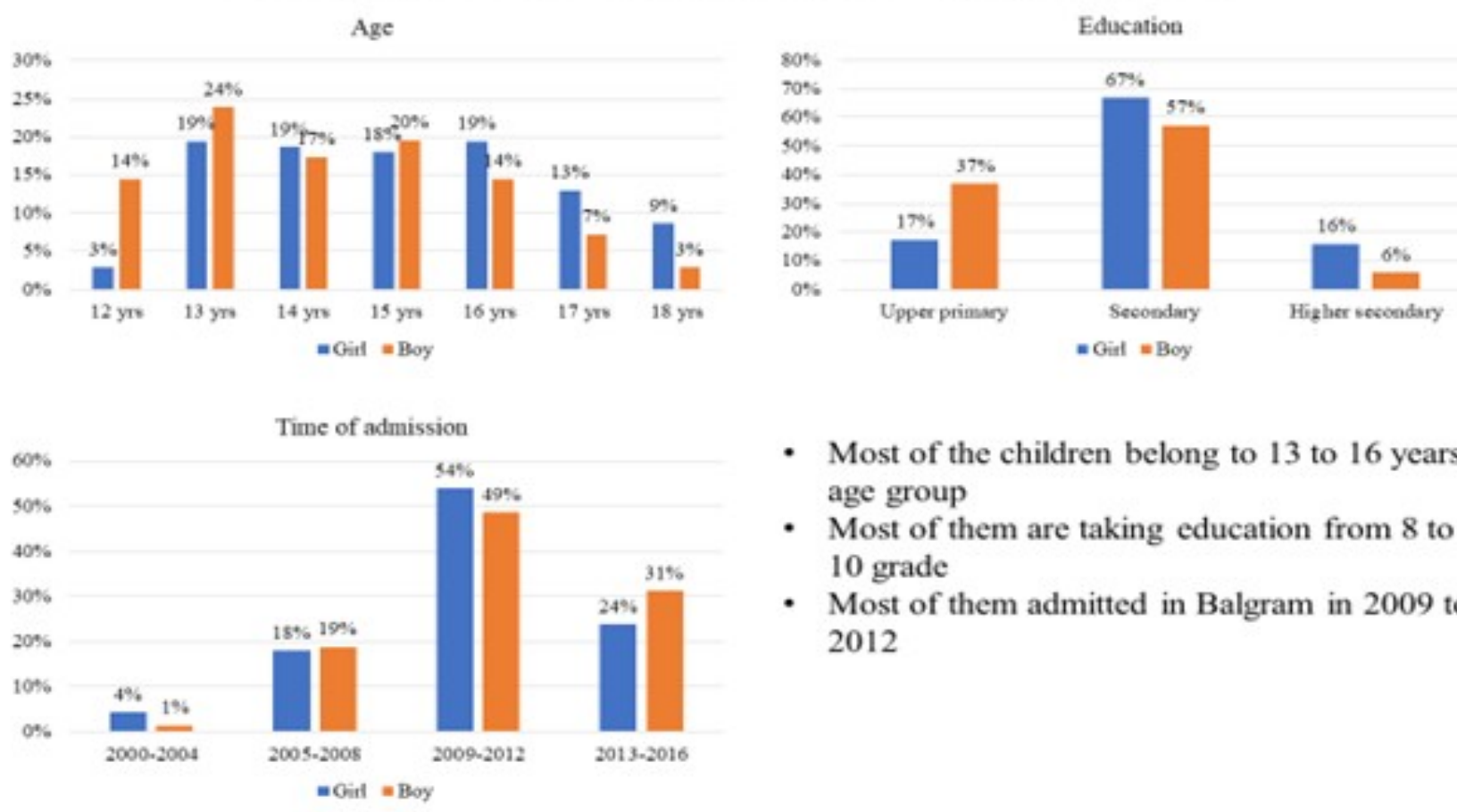

- Most of the children belong to 13 to 16 years age group

- Most of them are taking education from 8 to 10 grade

- Most of them admitted in Balgram in 2009 to 2012

\section{Hypothesis Testing}

Hypothesis 1: Socialization process of Balgram and rehabilitation of children are closely associated to each other

Provision of physical family environments: The Balgram has provided the family environment.

Provision of basic facilities: Children get house, food, clothing, educational material, physical and cognitive development related facilities.

Age appropriate education: All the admitted children in the Balgram are enrolled in the schools,

Balgram is providing the education as per their interest., There are certain limitation as per the age but Balgram ensures that the children get education which can give them livelihood.

Age appropriate physical development: Regular health checkup, food as per the recommendations of nutritional experts, Balgram is ensuring that the children are growing as per the normal trend of development.

Provision of coping mechanism system: The counseling facility is provided, Lots of extracurricular activities are provide to cope up with the unexpected situations. , The house mother, village

director, other non-teaching staff guide the children as per need.

Provision of facilities for physical and mental development : Karate and dance teacher, regular monitoring, regular school, indoor and outdoor games

Adoption of social etiquettes and manners: The Balgram teaches basis etiquettes and manners which help them to build a rapport with the society.

Creation of Social network : The children are enrolled in the public schools. It means that they have daily contact with the society. It help them to crate their social network which will help them to grow in the future.

Monitoring and supervision system: The Balgram staff and other visiting staff monitor the progress of each child. The separate file for each child is prepared to measure the progress of regular basis.

Firsthand experience on the daily routine activities Each child should be wake up early in the morning.

$>$ They should take daily bath.

$>$ They are not allowed to waste the food.

$>$ The quarrels are not allowed and they should leave as a family. 
$>$ They should respect and accept others.

$>$ They should follow the rules and regulations of the organizations. They should be involved in the day to day routine work.

Entertainment facilities: The indoor and outdoor games, TV, LCD, music system, auditorium and appointment of dance or karat teachers indicate that the Balgram has ensured that the children should get entertainment.

Information on social norms \& social culture: Balgram celebrate almost all the major festivals through which the children get the exposure of adoption of social norms.
Experience on participatory approach: The daily routine is prepared in such a way that they should work as a team. Each Sadan consists 8-10 children. All these provisions indicate that the Balgram is providing the participatory approach of working.

Scope for the development of personal skills: Balgram helps to develop minimum one personal skill which can give them livelihood. Apart from that the extra-curricular activities are planned to develop their personal skills.

Lifelong connectivity with the institution: It is expected that the pass out children should visit the Balgarm and guild the existing children. According to these expectations most of the children visit the Balgram.

\section{Rehabilitation}

\begin{tabular}{|c|c|c|c|c|c|}
\hline \multirow{2}{*}{ Respondents } & \multicolumn{4}{|c|}{ Socio-economic status } & \multirow[b]{2}{*}{ Total } \\
\hline & Upper & $\begin{array}{l}\text { Upper } \\
\text { middle }\end{array}$ & $\begin{array}{l}\text { Lower } \\
\text { middle }\end{array}$ & $\begin{array}{l}\text { Upper } \\
\text { lower }\end{array}$ & \\
\hline \multirow[t]{2}{*}{ Girl } & $\mathbf{0}$ & 7 & 24 & 6 & 37 \\
\hline & $0.0 \%$ & $18.9 \%$ & $64.9 \%$ & $16.2 \%$ & $100.0 \%$ \\
\hline \multirow[t]{2}{*}{ Boy } & 3 & 15 & 10 & $\mathbf{0}$ & 28 \\
\hline & $10.7 \%$ & $53.6 \%$ & $35.7 \%$ & $0.0 \%$ & $100.0 \%$ \\
\hline \multirow{2}{*}{ Total } & 3 & 22 & 34 & 6 & 65 \\
\hline & $4.6 \%$ & \begin{tabular}{|l}
$33.8 \%$ \\
\end{tabular} & $52.3 \%$ & $9.2 \%$ & $100.0 \%$ \\
\hline
\end{tabular}

In order to identify the association, $\chi^{2}$ test was applied. It was found that there is no significant association between the gender of the respondents and education $\left(\chi^{2}=16.749, \mathrm{df}=3, \mathrm{p} \leq 0.05=7.82\right)$.

\section{Conclusion}

Balgram children live in the lower middle category of life.

It proves that the rehabilitation of the Balgram children is not good as far as the provision and efforts taken by the Balgram is concern.

$>$ Ssocialization process of Balgram and rehabilitation of children are not closely associated to each other.
Hypothesis 2: Balgram play an important role in rehabilitation of the orphans/children in need of care and protection through socialization.

\section{Education}

Out of existing children 62 per cent respondents have education up to secondary level and very less (11\%) respondents have education up to higher secondary level.

As far as pass out children are concern 28 per cent respondents have completed their education up to diploma followed 26 per cent of the children have completed their education up to graduation. 
Each 23 per cent respondents have completed education up to post graduation and ITI.

$>$ Overall 49 per cent respondents have completed education up to graduation and post-graduation and 51 per cent have taken technical education.

All the children have minimum education. All this information indicates that the Balgram provides minimum education to the children.

\section{Socio-economic status}

$>$ As per the Kupuswami's socio-economic measurement scale the most of the children comes under lower middle category. As far as provision and efforts taken by Balgram is concern the socioeconomic condition is not good.

\section{Marital status}

$>$ The 86 per cent boys got married by the Balgram and none of them have married themselves.

$>$ All the married boys and 88 per cent girls also find it difficult to get the partner for life.

As far as marriage is concern almost all of them got the life partner.

\section{Conclusion}

$>$ Balgram treat the children in normal way.

$>$ They do not discriminate among boys and girls.

$>$ They give maximum exposure to the children.

$>$ To handle the orphan children is very challenging task because every child comes from the different background.

$>$ The financial constraint and the changing laws are some of the other areas which create the limitations to the organizations.

$>$ The overall data shows that most of the children are leaving the life in normal way.

$>$ Hence it can be concluded that the Balgram play an important role in rehabilitation of the children in need of care and protection through socialization.

$>$ The Balgram is taking lots of efforts to socialize the children but the children are not getting trained. Hence the more focused socialization is required.

$>$ The socio economic condition of the children is not good. The more focused livelihood training should be given to the children.

$>$ The Balgram should create a matrimonial site which will help them to identify a good life partner.
The Balgram should take required efforts to generate sufficient ID proof of all the children. The Balgram must ensure that each and every child should get the AADHAR card, PAN card, bank account and ration card before leaving the Balgram.

$>$ Scientific approach should be adopted to identify the personal interest and skills and according to that the additional inputs should be given.

$>$ The children should be trained in such way that they should manage their life after leaving the Balgram. Hence more exposure on the daily life situations should be given to all of them.

$>$ The network of pass out children should be created. It will help them to solve the practical difficulties of life.

$>$ The Balgram should start the advocacy at government level. The separate platform should be created so that the administrative and legal issues could be minimized.

$>$ The Balgram need to improve their MIS system. After leaving the Balgram the institute should have the records of pass out children.

\section{Suggestions}

1) The Balgram is taking lots of efforts to socialize the children but the children are not getting trained. Hence the more focused socialization is required.

2) The socio economic condition of the children is not good. The more focused livelihood training should be given to the children.

3) The Balgram should create a matrimonial site which will help them to identify a good life partner.

4) The Balgram should take required efforts to generate sufficient ID proof of all the children. The Balgram must ensure that each and every child should get the AADHAR card, PAN card, bank account and ration card before leaving the Balgram.

5) Scientific approach should be adopted to identify the personal interest and skills and according to that the additional inputs should be given.

6) The children should be trained in such way that they should manage their life after leaving the Balgram. Hence more exposure on the daily life situations should be given to all of them.

7) The network of pass out children should be created. It will help them to solve the practical difficulties of life. 
8) The Balgram should start the advocacy at government level. The separate platform should be created so that the administrative and legal issues could be minimized.

9) The Balgram need to improve their MIS system. After leaving the Balgram the institute should have the records of pass out children.

\section{Suggestions for proper rehabilitation children who are above 18 years}

1) Orphan child should get self-identity documents like an orphan certificate, Ration card, Aadhar card and voting card on permanent address of their own institute.

2) Every district should have a youth homes/ After care homes separates for girls and boys. These homes must maintain properly, where children should feel and attract to stay and take their higher education or develop professional skills.

3) Every institute should develop Child Rehabilitation Fund, which could be utilise for higher education of the child those who are above 18 years.

4) Government should support the Orphan Child and treat a special class child (reservation) as a result every child will get an opportunity to take higher education and finally child will get good pay jobs.

5) Needy and homeless children should get affordable/ low cost homes from government schemes likes; Gharkul, MHADA, CIDCO and rural area. Government should make available reserve land for orphan

6) Government and NGO should support every orphan should get married and support him as guardians.

7) Those who wants to start their business these children should get proper support, guidance and economical/ financial support in term of sponsorship or business loan. $t$

8) Every institute start "Child Gift Money" scheme in which scheme institute will deposit certain amount from right child hood till the age of 18 years. This amount will be support the child to start his own life. He could start his business or able to invest in home.

9) State and Central Government develop a rehabilitation policy as a result every child get rehabilitate and every child become a part of society and enjoy all human rights of India.

10) The children who are economically sound enough, they should support their institute. Even they should directly support the children who are in process of rehabilitations.

11) Government should make compulsory to industries to utilise their CSR funds for rehabilitation of institutional children.

\section{References: Journals and report}

1) Child Adoption Policies in India- A Review, Paper presented by A.S. Shenoy, Chair, International Relations Committee, Indian Council of Social Welfare, Mumbai, 1st International Conference on Inter- country Adoption organized by Child NGO Federation- Nepal at Katmandu, Nepal on 10th, 11th and 12th March 2007

2) Health Administrator Vol : XX Number $1 \& 2: 44$ $48 \mathrm{Pg}$.

3) Results of the Orphans and Vulnerable Children Head of Household, Baseline Survey in Four Districts in Zambia, USAID/Zambia, Displaced Children and Orphans Fund, SCOPEOVC/Zambia, Family Health International, 31 October 2002

4) ORPHANS AND VULNERABLE CHILDREN IN INDIA: Understanding the Context and the Response, Report on Town Hall Meeting, The Aspen Institute Conference Center, Washington, D.C., June 2, 2003

\section{Web sites}

1) http://thirdworldorphans.org/gpage $39 . \mathrm{html}$

2) http://crlc.info/?p=223

3) http://en.wikipedia.org/wiki/Orphanage

4) http://www.avert.org/aidsorphans.htm

5) http://www.wisegeek.com/what-is-an-orphandisease.htm

6) http://www.nacac.org/policy/researchchart.html

7) http://family.jrank.org/pages/1239/Orphans.html

8) http://www.nytimes.com/2009/12/18/health/resear $\mathrm{ch} / 18 \mathrm{child} . \mathrm{html}$ ? $\mathrm{r}=1$

9) http://www.bibletruths.net/archives/BTAR277.ht $\mathrm{m}$

10) http://www.socwork.net/2009/1/special_issue/men gkai

11) http://lifestyle.iloveindia.com/lounge/adoptionlaws-in-india-169.html 
12) http://www.ccih.org/resources/compendium/Mode 1s\%20of\%20Orphan\%20Care\%20in\%20Malawi.h tml

13) http://family.jrank.org/pages/1238/Orphans-

Summary.html

14) http://en.wikipedia.org/wiki/Socialization

15) www.soscv.india

\section{Other}
1) Constitution of India
2) Human right
3) Indian Penal Code 